(Field Note)

\title{
A Long-Term and Large-Scale Research of the Lambir Rain Forest in Sarawak: Progress and Conceptual Background of Japanese Activities
}

\author{
Takuo YAMAKURA Department of Biology, Faculty of Science, Osaka City University, Osaka 558, Japan \\ Isamu YAMADA Center for Southeast Asian Studies, Kyoto University, Kyoto 606, Japan \\ Tamiji INOUE Center for Ecological Research, Kyoto University, Otsu 521-01, Japan \\ Kazuhiko OGINO Department of Forestry, Faculty of Agriculture, Ehime University, Matsuyama, 790, Japan
}

\begin{abstract}
A long-term and large-scale research of a tropical rain forest was initiated at the Lambir Hills National Park in Sarawak in 1990. The research successfully passed the first turning point by establishing the 52 ha research plot, tree tower and walkway system, and laboratory facility within the park in 1994. The historical descriptions of the background concept and progress of Japanese activities during recent five research years were briefly given for the following purposes, 1) to promote the similar researches at another localities, 2) to declare an initiation of canopy biology by describing its definition, and 3) to offer a conceptual background for the research results expected to appear in this journal in the nearest future.
\end{abstract}

Key Words: biodiversity / canopy biology / ecosystem management / global warming / long-term / large-scale / monitoring / resources / Sarawak / tropical rain forest

A long-term and large-scale research (LTLSR) of a tropical rain forest was initiated on a hilly slope of the Lambir Hills National Park ca. $4^{\circ} \mathrm{N}$ in latitude and ca. $114^{\circ} \mathrm{E}$ in longitude in Sarawak, East Malaysia in November 1990, through the international collaboration among foresters, dendrogists, ecologists, and botanists from the three countries, Sarawak, Japan and U.S.A., though the participants from U.S.A. could join the field work from the year of 1991 . The concept of LTLSR has its origin in the monitoring of the natural events and its significance is well known, as described elsewhere (e.g., Hubbell \& Foster, 1983; Likens, 1989; Yamakura, 1992, 1993 , 1994).

At Bangkok in March 1988, Mr. Hua Seng Lee (H.S.L.), Assistant Director of Forests (Research) at Forest Department Sarawak, Dr. Peter Shaw Ashton (P.S.A.), Professor of Arnold Arboretum at Harvard University, and one of us (T.Y.), representing the participants from Sarawak, U.S.A., and Japan, respectively, agreed with the initiation of LTLSR at Lambir and decided to devote their best efforts for funding. It involved an establishment of a largescale research plot of 50 ha in area, which was expanded to 52 ha later. The purposes of LTLSR first declared to the Sarawak state government by the Sarawak research organizer Mr. H.S.L. were; 1) to monitor tree population dynamics in space and time, with reference to the regeneration of key stone species and timber species; 2) to analyze the interaction among 
species at two contrasting local soils, sandy and clayish soils, characterizing the Lambir Hills; 3) to provide control observations for silvicultural studies proposed on the basis of the first forestry inventory results; and 4) to establish a foundation of botanical knowledge indispensable for wildlife biologists, socio-economists, and park managers (Lee, 1992). These purposes were either silvicultural or forest ecological, adapted for the forestry situation in Sarawak, adaptable to small budget situations in two of us (T.Y. \& Dr. P.S.A.), and partly constrained by the first research proposal submitted to the Sarawak state government by T.Y. in 1990, since a research proposal from Dr. P.S.A. to the Sarawak state government came later in 1991. Thus, the research of LTLSR in 1990 was inevitably initiated in rather modest scale in its activities by two of us (Mr. H.S.L \& T.Y.), though its background concept was not modest and included scientific difficulties, which are worth while to challenge for scientists in the tropics, as described later.

In parallel with the aforementioned initiation of LTLSR, an another research project was initiated in Japan. It was entitled "Studies of Global Environmental Change with Special Reference to Asia and Pacific Regions: Integrated Development of Environmental Sciences of the World", leaded by Dr. Saburo Tamura (Emeritus Professor, Tokyo University, JPN), and supported by a Japanese Monbusho (Ministry of Education, Science and Culture, Tokyo) foundation of "Creative Fundamental Research (CFR)". Here, the project is tentatively designated CFR for the abbreviation of the aforementioned long project name. Some of senior participants of CFR had a recognition study at Lambir in January 1991 and decided to support the research already initiated at Lambir. The acceptance of the CFR's support successfully extended the original purposes and activities of LTLSR. The project as a whole entity of our activities at Lambir has passed the first turning point in research progress by the establishment of the 52 ha research plot, tree-tower-walkway-system, and laboratory facility at present 1994. All these facilities are expected to contribute to further researches of tropical rain forest in Sarawak. This paper describes the conceptual background and progress of Japanese activities, by clearly drawing a project outline. We believe, descriptions of step-wise research progress will be helpful in planning similar projects in the future. The descriptions will also be available for understanding well the Lambir rain forest, of which details will be described in separate papers in this journal (e.g., Yamakura et al., in contribution). Furthermore, the descriptions should be shared among all the Japanese project participants at Lambir, including new participants who may visit or work at Lambir in the nearest future.

\section{PREPARATION OF THE RESEARCH LTLSR}

\section{Days Before Our Entrance into Sarawak}

After a momentum brilliance at Pasoh in Peninsular Malaysia at the JIBP era around 1970 in a history of Japanese tropical rain forest researches, the major research projects tended to be confined to wet land formations, such as mangroves (e.g., Ogino, 1991), though the reasons of shifts in target forests are beyond the scope of this paper. The Japanese researches in dry land forests were rather minor during 1975-1990. The researches in dry land forests retrogressed, except one rare project extended in Sumatra, Sumatra Nature Study (SNS), organized by Dr. Syunzo Kawamura (Emeritus Professor, Kyoto University, JPN). Two of us (K.O. \& T.I.) were enrolled in SNS as major participants (Hotta, 1984). K.O. worked for the research plot establishment for the long-term observation of Sumatra rain forest, while T.I. 
monitored insect populations in kitchen gardens or vegetable farms (Sakagami et al., 1990). One of us (I.Y.), as a JICA expert, engaged in the research of rich rain forest at Brunei (Yamada, 1991) and had a contact with Mr. H.S.L. in Sarawak. The other one of us (T.Y.) strolled Indonesian Borneo, searching for a better site for establishing a permanent research plot (Yamakura et al., 1986) and following a research tour organized by Dr. Husato Ogawa (Emeritus Professor, Osaka City University, JPN). For the most of Japanese forest scientists, Sarawak had looked so steep and severe for their entrance there, owing to their ignorance of hearty Sarawakians and kind Sarawak state government. They might feel awkward or selfconscious in coming there.

\section{Narrow Door Opened by an Aid of Professor Peter Shaw Ashton}

Dr. P.S.A. is familiar to Japanese tropical ecologists by his excellent paper appeared at the commencement of the first volume of this journal (Ashton, 1991), in addition to his wellknown and amazing unprecedented contributions to tropical dendrogy, ecology, and botany. He was an old friend of Dr. Mitsuru Hotta (M.H.) (Professor, Kagoshima University, JPN), since Dr. M.H. first visited North Borneo in 1963 and 1964. Really, Dr. M.H. was one of the rare Japanese botanists who botanized Sarawak and Brunei at the difficult era after the World War Second. Sarawak rain forest should be coined in our Japanese recognition through the pioneer works by Dr. M.H. and his colleagues (Hotta, 1964, 1965, 1967).

One of us (T.Y.) had send a manuscript of a paper describing his first experience in Indonesian Borneo to Dr. P.S.A. in 1984, to ask Dr. P.S.A.'s review for the manuscript. Dr. P.S.A. was kind enough to review it and implied to T.Y. that Dr. P.S.A. can help T.Y., if T.Y. is eager to come to Sarawak. This implication from Dr. P.S.A. was really a thin string of light that resulted in the recent Japanese researches of LTLSR in Sarawak. Following the subtle light emitted by Dr. P.S.A. in a dark night era in Japanese forest researches in dry land forest formations, T.Y. visited Harvard University, at which Dr. P.S.A. was the director of Arnold Arboretum. It was cold and gloomy January in 1986, when T.Y. first met with Dr. P.S.A. at the herbarium library of Harvard University. T.Y. asked Dr. P.S.A. to help T.Y.'s entrance into Sarawak. Dr. P.S.A. kindly wrote a letter to the Assistant Director of Forest (Research: Mr. H.S.L.) to accept a modest research by T.Y. and T.Y.'s classmate Dr. S.K. (Professor Shigeo Katagiri, Shimane University, JPN) in Sarawak in 1986, when the job title of both T.Y. and Dr. S.K. was the university assistant in Japan.

T.Y. stayed at Harvard University one month and enjoyed Cambridge and Boston. Before leaving Harvard University to Japan, T.Y. requested Dr. P.S.A. to visit once Japan for the exchange between Dr. P.S.A. and Japanese tropical ecologists. When T.Y. returned to Japan from U.S.A., T.Y. asked Dr. Husato Ogawa to apply for a financial aid of JSPS for inviting Dr. P.S.A. to several Japanese Universities, Ehime, Kagoshima, Kyoto, and Osaka City Universities. Dr. H. Ogawa willingly agreed with T.Y.'s asking and took a quick response for funding for having Dr. P.S.A. in Japan. Fortunately, Dr. H. Ogawa's asking was kindly approved in 1987 by JSPS, to which we were most grateful.

\section{First Sarawak}

After returning Japan from U.S.A., T.Y. prepared for going to Sarawak. Monbusho Tokyo was kindly enough to support the research in Sarawak and had already approved a financial support for the two assistants' (T.Y. \& Dr. S.K.) research in Sarawak in 1986, when the 
research by only assistants was seldom approved by Monbusho, Tokyo. The Sarawak state government was also very much kind in approving the two Japanese assistants' research in his territory, though T.Y. felled in a critical pit, where T.Y. might loose any Japanese scientific qualification in conducting overseas researches, owing to time lag in correspondence between Sarawak and Japan. T.Y. was also much obliged to the Forest Department Sarawak, Mr. H.S.L., the Senator Mr. Tiong Hiew King, and Mr. Toshiyuki Wake for their kind consideration and support extended for T.Y.'s entry into Sarawak.

In December 1986, T.Y. and Dr. S.K. could finally come to beautiful and cozy Kuching, the capital of the Sarawak State, colored with perpetual green. Here in Sarawak, which had been a kind of dream lands to T.Y., peoples were friendly, kind, and perfect in treating strange young Japanese forest ecologists. Two of them were very much happy, visited the Bako and Lambir National Parks, and conducted the honest researches of tree fall patterns and soils during their three month stay there, under generous support to them from Mr. H.S.L. and the Forest Department Sarawak (Katagiri et al., 1991). Two Japanese were impressed by a fact that topography in Sarawak is very steep and complex as in Japan. They learned the important effects of topography and soil on forest structure and floristic composition, as written by Dr. P.S.A. (e.g., Ashton, 1964) and his colleagues (Austin et al., 1973; Baillie \& Ashton, 1983; Baillie et al., 1987). They arrived at a working hypothesis as following that forest knowledge derived from temperate Japanese forests standing on very complex topography might be successfully applied to the better understanding of Sarawak rain forests, since the topography and topographic change in soils in Sarawak looked quite similar to those in Japan. At that time, a prevailing thinking in Japan agreed with the unavailableness of Japanese knowledge for understanding tropical rain forest, since Japanese forest knowledge had been obtained from temperate forests, which have been believed to be quite different from tropical rain forests. Furthermore, two of them intuitively understand that the Lambir rain forest will offer a better research site for comparative studies with respect to the effects of local topography and soil upon local changes in forest architecture, composition, and dynamics. The big local variations in forest structure and composition within a forest is a characteristic feature of Bornean rain forest. Hence, a possible cause of the variations has been a focal ecological question in forest researches, though its proposed explanations fluctuated between two contrasting hypotheses; the environmental determinism (e.g., Ashton, 1964) and biogenic causality, such as the forest growth cycle emphasized by Dr. T.C. Whitmore (1984). Before leaving Sarawak with happy memories, T.Y. requested Mr. H.S.L. to come Japan for the discussion of research results in 1986 and further possible cooperation in the future.

\section{Personal Exchange between Sarawak and Japan}

In winter 1987, Mr. H.S.L. had a short visit to Japan with his family. He stayed at Osaka and Matsue, and gave his lectures to graduate students at Osaka City University. He recognized Japanese researches of tropical rain forest by young university staffs and might decide his attitude in supporting Japanese researches planned by powerless young Japanese foresters. Mr. H.S.L. also visited one of us (I.Y.) working at the Forest Tree Breeding Institute of Japanese Forestry Agency at Mito City. Mr. H.S.L. talked about with three of us (T.Y., I.Y. \& Dr. S.K.) during his stay in Japan, concerning a possibility of further cooperative researches between Sarawak and Japan. However, none of them including Mr. H.S.L. could think about 
LTLSR in Sarawak, since they had just stood on a starting point of an international cooperative research between individuals.

\section{Brunei Rain Forest as the First Research Target}

One of us (I.Y.) was on a hospital bed at Kyoto for a heavy liver trouble gotten in Brunei in autumn 1986. On the bed, I.Y. reconsidered his all activities so far conducted by him in Asian tropical forests during over 20 years and was thinking about a new research, which should take a new research style and should be planned in the nearest future. His reconsideration and new thinking gave great influence over the planning of LTLSR at Lambir later. After recovering from the sickness in December 1986, I.Y. returned to his office at Mito in 1987 and began to write his experience in Brunei (Yamada, 1991). When Mr. H.S.L. came to Japan in winter 1987, he visited I.Y. in the early December 1987, as already described.

In April 1988, I.Y. suddenly left his office at Mito to the new office at Kyoto University, where he had worked in former days as a university assistant. The first work, which I.Y. did at the new office, was a recognition study of the neotropical rain forests. From May to June in 1988, he visited U.S.A., Central- and South America and attended an international meeting entitled "OTS Jubilee Symposium" and held at Miami. Through the research travel and the meeting, I.Y. met with major researchers of tropical rain forests of the world including Dr. P.S.A., who had already received an invitation letter from Dr. H. Ogawa and was preparing to visit Japan around September in 1988. I.Y. and Dr. P.S.A. friendly talked about their memories in Brunei and exchanged their opinions concerning a possibility of an international cooperative research of rain forest in Brunei. Before coming to Japan in autumn 1988, Dr. P.S.A. send a letter to I.Y., inquiring the possibility of LTLSR in Brunei by using the financial support from JICA, which was believed by Dr. P.S.A. to be the powerful and best Japanese government foundation for supporting LTLSR of tropical rain forest, since LTLSR in Dr. P.S.A.'s recognition purposed first to provide better information for policy development, as described in the next section. Therefore, LTLSR in north Borneo had been first planned in Brunei and never planned in Sarawak, according to our memories.

\section{Not by Timber Alone: Work by ITTO and HIID}

The International Tropical Timber Organization (ITTO) was established in 1986, under an international treaty as a forum for consultation and cooperation to promote the conservation and wise utilization of tropical forest resources of the world. It had just commenced operations at its headquarters at Yokohama in 1987, when we began to access to Sarawak. ITTO with the Executive Director of Dr. B.C.Y. Freezailah from Kuala Lumpur at Peninsular Malaysia, an old friend of Dr. P.S.A., commissioned the Harvard Institute for International Development (HIID) to examine the sate of knowledge on multiple-use management of tropical hardwood forests and the potential role that non-timber forest products and services can play in the sustainment of the forests. This commission from ITTO to HIID in 1987 aimed to search for a possible path for the integration of nature conservation and economic growth in timber producing countries, avoiding a stereotyped ecological disaster or confliction between two different requirements, conservation and development. Following the research policy of ITTO and HIID in 1987, Dr. P.S.A. and his colleague, Dr. Theodore Panayoto (Lecturer, Department of Economics, Harvard University) began to study to answer the commission from ITTO, by reviewing the tropical forest resources and timber trade, 
natural forest management, and undervaluation of tropical timber, by summarizing the importance of non-timber products and environmental services from the forest, and by analyzing the economics of multiple-use forest management, including some detailed technical problems, such as logging technologies, enrichment planting silviculture, and plantation forestry. In a course of the progress of the reviews and analysis, Dr. P.S.A. and his colleagues arrived at some recommendations for the further research and economic development. They expressed the recommendations in the form of policy and research agenda consisted of several articles, one of which emphasized a necessity of the construction of an international network of LTLSR established at different countries, as described later. The results of their studies became to be compiled later in a book entitled "Not by Timber Alone" and written by Dr. T. Panayoto and Dr. P.S.A. (Panayoto \& Ashton, 1992).

\section{Discussion Among Japanese Tropical Ecologists}

Dr. P.S.A. with his family shortly stayed in Japan, when he returned to U.S.A. from Brunei, where he had a research for the aforementioned ITTO commission. He arrived at Narita with his hopeful business of LTLSR and new hot data from a 50 ha plot at Pasoh on 1 September 1988. He visited Tokyo, Kyoto, Osaka, and Kagoshima and talked about the necessity of LTLSR in Asian countries with major Japanese tropical forest researchers working in Southeast Asia, referring the cases at BCI in Panama and Pasoh in Peninsular Malaysia. Dr. P.S.A. and one of us (I.Y.) had detailed discussion at I.Y.'s office at Kyoto University with respect to an initiation of LTLSR in Brunei, including a funding strategy. I.Y. had the close connections with Brunei and powerful JICA's research budget through his long research experience. Hence, he was thought to be the best Japanese organizer of LTLSR in Brunei, as already described. I.Y. summarized the discussion and prepared a brief note, which was submitted to a closed meeting of seven Japanese tropical ecologists and Dr. P.S.A. The document written by I.Y. described the followings:

1) permanent sample plots with different environmental characteristics in terms of climate, soil, and biogeography,

2) practical procedures including a) field training for field work staffs at Pasoh, b) the survey and griddling of a 50 ha plot, c) the labeling, mapping, tree size measurement by dbh, and identification of individual trees, d) the completion of the 50 ha inventory, e) the canopy and canopy gap mapping, f) the data processing, and g) the publication,

3) necessary staffs consisting a)field survey staffs, b) field leaders with P.H.D., c) assistant field leaders with P.H.D., d) specialists for identification, e) computer analysts, and f) advisors,

4) a total budget of ca. 800,000 US $\$$ including equipments and salaries for field staffs,

5) Japanese funds for overseas research from JICA, Monbusho, and private fund organizations,

6) candidate countries for research sites including Brunei as the first and Sarawak as the second, and

7) research subjects consisting of a) population ecology, b) population genetics, c) community ecology, d) production ecology, e) phenology and pollination ecology, f) gap dynamics, and $\mathrm{g}$ ) nutrient cycling.

The meeting was held at Osaka in the evening 12 September 1978. The aforementioned 
seven Japanese attendances at the meeting were: Dr. H. Ogawa, Dr. Kyoji Yoda (Professor, Osaka City University, JPN), Dr. Hiroyuki Watanabe (Professor, Kyoto University, JPN), Dr. Mamoru Kanzaki (Assistant, Osaka City University, JPN), and three of us (K.O., I.Y. and T.Y.). We freely talked about the possible international collaboration among Asian countries and U.S.A., in addition to the discussion of research subjects. Similar meetings had already organized at Jakarta in Indonesia and at Colombo in Sri Lanka. These preliminary discussions offered a better basis for the Bangkok Workshop described in the next section. At this stage for the preparation of LTLSR, the Japanese LTLSR research site was thought to be built in Brunei not in Sarawak, although T.Y., in his concealed selfconsciousness, had decided to devote continuously his modest effort to establish the LTLSR plot in Sarawak, whose forest should be the next Japanese research target after the establishment of the LTLSR site in Brunei.

\section{Bangkok Workshop}

After the meeting at Osaka in September 1988, one of us (I.Y.) began to contact with several research agencies including JICA at Tokyo for funding. Through I.Y.'s funding effort, we learned many Japanese government research programs similar with LTLSR in their conceptual background.

In parallel with I.Y.'s effort in Japan, Dr. P.S.A. was preparing an international workshop sponsored by U.S. National Science Foundation (NSF) and U.S. Agency for International Development (USAID), for the construction of a research network of LTLSR sites. The workshop was entitled "Funding Priorities for Research Towards Effective Sustainable Management of Biodiversity Resources in Tropical Asia" and held at Bangkok between 27th and 30th March 1989. It purposed to define funding priorities for policy-oriented researches on two vulnerable biomes endemic to tropical Asia and outstanding for their biodiversity: tropical rain forests and coral reefs. Fifty-five workshop participants included scientists representing several biological and social disciplines, which are theoretical and applied, from eight Asian countries (China, India, Indonesia, Malaysia, Philippines, Singapore, Sri Lanka, and Thailand) with tropical forests, Australia, Canada, F.R. Germany, Japan, and U.S.A. From Sarawak, Mr. H.S.L. attended the workshop, actively contributing to the progress of discussions. No participant from Brunei was recognized, since motives for LTLSR might be weak there.

Three Japanese attended the workshop. They were Dr. Ryosuke Kato at JICA, Dr. Koichi Kamo at JICA, and one of us (T.Y.). An another one of us (I.Y.) could not attend the workshop owing to his miscellaneous activities at his office in Kyoto, though Dr. P.S.A. send an invitation letter to I.Y., strongly requesting I.Y.'s attendance to the workshop. Dr. R. Kato and Dr. K. Kamo were working at the JICA office at Bangkok for a big forestry project sponsored by JICA at that time. According to Dr. R. Kato, a workshop organizer send a letter to the JICA office in U.S.A. to dispatch two of us (I.Y. and T.Y.) to the workshop. This request from the workshop organizer to JICA was unacceptable to JICA, which sent Dr. K. Kato and Dr. K. Kamo to the workshop for the substitute of the denial of the workshop organizer's request. The absence of I.Y. at the workshop was greatly regretful, since it might consequently cause an abortion of LTLSR in Brunei.The discussions were done at separate sessions of two biomes: forest and coral reef. In the forest session, discussions trod the following path (Ashton, 1989).

1. The deforestation and overexploitation of forest has nevertheless proceeded longer and 


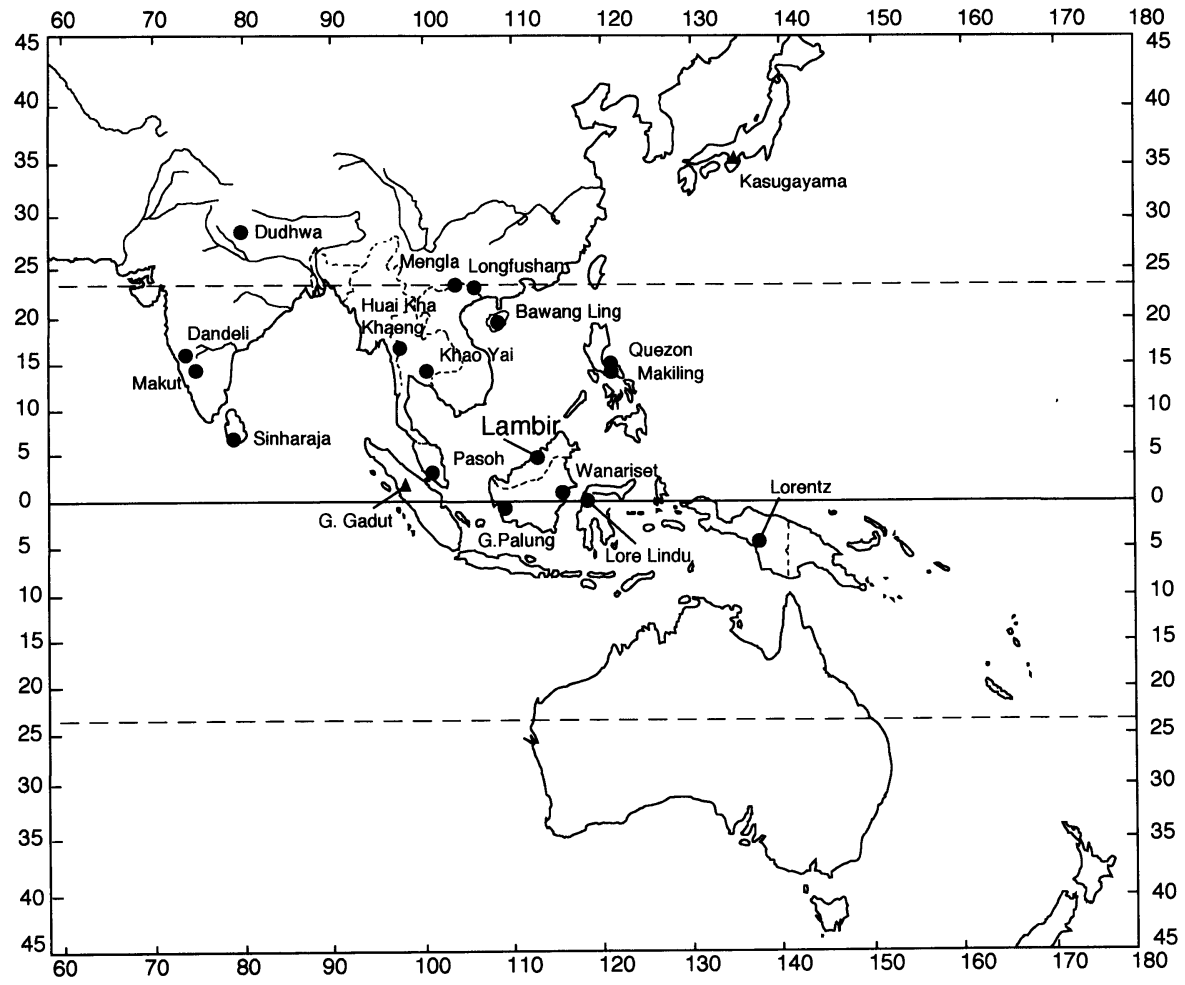

Fig. 1. Regional distribution of long-term and large-scale research forests proposed at the Bangkok Workshop . A closed triangle at G. Gadut in Sumatra represents a research site established by a Japanese research, SNS, (Hotta, 1984). A research site at Kasugayama represents one of research sites for large-scale and long-term ecological researches in Japan.

is more extensive in tropical Asia than elsewhere in the tropics. Therefore, the international cooperative efforts are necessary to define priorities for researches which can enable Asian societies to reach a new sustainable dynamic between man and his surroundings.

2. The goal of discussions has been to design a plan for utilizing the available scientific skills of the region in conducting policy-oriented research at the minimum level, which is required for sound policy decision making, covering the major tropical forest ecosystems in the region. A policy relevant research requires the close integration of social and biological sciences, including forestry, agro-forestry, economics, social anthropology, ethnobiology, pedology, conservation science, hydrology, population biology, and systematics.

3. The recognition of the urgency of issues and the limited human and institutional resources with appropriate skills and experiences can lead us to consider that the researches should be planned to yield early results, which can be refined and broadened through longer term studies. This overall strategy requires a) the identification of research sites, which are representative ecosystems of regional significance and available for at the least ten-years and b) the establishment of a series of Long-Term Management Research Sites, which are analogous to the N.S.F.-sponsored-and-funded Long-Term Ecological Research Sites and are differing only in the policy oriented thrust of their research goals. The respective research sites should be equipped by the Large-Scale Research Plot of 50 ha, which is a core facility of multi-purpose use in scientific researches, resource conservation, etc.

4. All the research sites for LTLSR in different countries are combined with each other by 
an international research net work, through which research participants can share common standardized research methodologies for easy comparison of research results (The Center for Tropical Forest Science at the Smithsonian Tropical Research Institute has recently begun to work for the network.).

5. Following the above discussions, seventeen LTLSR sites in the Asian region were proposed by the representatives from the aforementioned eight Asian countries and their positions were compared (Fig. 1).

Our colleague Mr. H.S.L. introduced the Lambir Hills National Park as the best research site for LTLSR in Sarawak. Dr. P.S.A. and Dr. Eberhard F. Bruenig (Professor, Hamburg University) recommended H.S.L. and T.Y. to establish a 50 ha research plot at Lambir by close cooperation between several countries concerned. A duty entrusted to T.Y. was a funding effort in Japan for the initiation of LTLSR at Lambir and made T.Y. gloomy, since a funding ability of T.Y. was lower in Japan. Kind Mr. H.S.L. encouraged T.Y. by suggesting that T.Y. shall establish the plot by the help from Mr. H.S.L.

After returning Osaka from Bangkok, T.Y. visited I.Y. and one of us (K.O.) and reported the details of the workshop to them. K.O. recommended T.Y. to send a research proposal to a Monbusho's overseas research fund. T.Y.'s research proposal was sent to Monbusho in June 1989 and was generously accepted by the ministry in the early 1990 (Grant No. 02041071). The National Institute for Environmental Studies of Japan (Global Environment Research Program Granted by Japan Environment Agency, Grant No.E-2) also kindly supported T.Y. by defraying a budget in 1990. T.Y. is the most grateful to the two government funding agencies including a personnel effort of Dr. Akio Furukawa, since LTLSR at Lambir could not start without their help.

\section{Impact of The Japan Society of Tropical Ecology on LTLSR}

One of us (K.O.) and his colleagues had devoted their efforts for newly establishing a Japanese academic society of tropical ecology (JASTE) since 1989, for the advancement of ecological studies in tropical areas and the exchange and propagation of research achievements among professional researchers and the public. It commenced its operations with the President Dr. Tatuo Kira (Director, Lake Biwa Institute, Shiga, JPN) at its headquarters at Matsuyama, Ehime Prefecture in August 1990.Thanks to several academic meetings of JASTE, we could meet many senior Japanese tropical ecologists, who were very kind in offering us the relevant advice with respect to LTLSR in Brunei and Sarawak. For example, three of us (K.O., I.Y. and T.Y.) could have a contact with ITTO by the kind arrangement of Mr. Katsuhiro Kotari, who was one of auditors of JASTE, a VIP of JICA, and one of senior Japanese members of a ITTO mission, which had already been sent to Sarawak by ITTO in 1989 and 1990 for an evaluation of commercial logging extended in Sarawak around an era of 1990. From the senior members of JASTE, we learned rich information about overseas research activities by Japanese government and nongovernment budgets. We might need a powerful professional research broker to get a financial support from funding organizations, such as ITTO and JICA, since we, public university staffs, stood on a position very far from any ODA agencies at Tokyo.

\section{Canopy Biology}

In parallel with the preparation for the 50 ha plot for an initiation of LTLSR in Sarawak, we 
were thinking about an access to a new research field that had seldom accepted any human activities there. To a man as an ape falling down to the earth ground from the supreme forest canopy, the canopy is analogous to the space because man has already lost their ability to climb up there by his own exertions without using any modern equipments and facilities. Thus, forest canopy still remains as an unknown continent of scientific adventures even in the 20th century, though it is conceptually recognized well that the canopy is a hot focal point of diversified forest lives. One of us (K.O.) was eloquent in emphasizing a necessity of canopy researches, which should bring indispensable information for forest rehabilitation by compiling direct observations on variety of biological phenomena extended by forest lives. K.O. pick up one of us (T.I.) for canopy researches and hoped to enroll T.I. to the members of LTLSR in Sarawak by using the budget of CFR described later. We believed the future and creativity of canopy researches and proposed "Canopy Biology" as an issue of tropical biology. It is a science of biological interdependency, which exists between canopy organisms or between organisms and their environment in forest canopies. There exist lives who spend all their lifetime in the tall canopy without visiting the ground. These lives are not easily recognizable by the observation at the ground level, as we can not survey the biological world of the deep sea bottom from the surface of the sea. Therefore, canopy biology will offer an effective access toward the understanding of unknown canopy lives with rich biodiversity, as suggested by several preceding studies (Erwin, 1983, 1988).

\section{INITIATION OF THE LONG-TERM AND LARGE-SCALE RESEARCH IN SARAWAK}

\section{Lambir Rain Forest}

Deep leached yellow soils overlying Neogenic sediments form an island of low hills between the major rivers issuing out of northwest Borneo and supports mixed dipterocarp forest with tall stature. Forest architecture is huge and is characterized by the complex and verticallystratified structure with superimposed horizontal layers. Topography is hilly and complex, is expressed by a term "broken topography", and seems to fragment a whole entity of plant habitats into small local fractions, which should be strongly combined with the richest lowland rain forest flora of the Old World (Yamakura et al., in contribution).

There is exceptionally high local endemism (c. 35\%) and Borneo Island wide endemism at c. $75 \%$. The reason for the exceptional biodiversity is unclear. Tree species diversity reaches its zenith on relatively infertile soil. Soil related plant community variability further adds to overall species diversity. However, biogeographical patterns also suggest that this region, from the mouth of the river Kapuas in West Indonesian Borneo to the extreme south west of Sabah, may have experienced less climatic changes during the north temperate glaciations than most other lowlands in the region (Ashton, 1989).

\section{Plot Demarcation}

T.Y. came again to Sarawak in March and April in 1990 to confirm the detailed research site in Lambir because Monbusho had already informed T.Y. that the research proposal by T.Y. will be approved. On 17 April 1990, Mr. H.S.L. and T.Y. walked about the park area to overview the plot area and to determine the first land mark position for plot demarcation, loosing their way in their wandering. T.Y. had also a short trip to the Bukit Mersing, where there is a 
permanent ecological research plot that was established by Forest Department Sarawak and Dr. P.S.A. about 25 years ago. Before the initiation of LTLSR at Lambir, T.Y. hoped to confirm the superiority of the Lambir rain forest compared with the Bukit Mersing rain forest, which was the grandest in forest architecture among the study forests managed by Mr. H.S.L.

In July 1990, T.Y. visited again the Lambir rain forest together with Dr. P.S.A. to talk about the concrete position of the plot, though they could misunderstand between each other with respect to a plot position, as will be described in a separate paper (Yamakura et al., in contribution). T.Y. checked equipments and materials already prepared for plot establishment after leaving Kuching at the end of July 1990.

The first land mark post for plot demarcation was established within a forest canopy dominated various dipterocarp species on 2 November 1990. It took about four years to finish all the necessary field and laboratory work for plot establishment. Further details are abbreviated here, since they are given in separate papers (Yamakura et al., in contribution; Chai et al., in press).

LTLSR at Lambir was thus launched in November 1990 by close cooperation among three countries. However, it had been acutely suffering from the shortage of research budgets owing to the expensive cost for the construction of the 50 ha research plot. To solve budget troubles, T.Y. was very much eager to search for a possibility of the further aid from another Japanese funding organizations. Fortunately, a budget support became to be supplied by a big research project, CFR, leaded by the Dr. Saburo Tamura, as described below.

\section{CREATIVE FUNDAMENTAL RESEARCH (CFR)}

\section{CFR and Its Project SGEC}

According to Dr. Saburo Tamura, the leader of the aforementioned CFR sponsored by Monbusho, CFR is a research fund entitled "Grant-in-Aid for Creative Fundamental Research" newly established by Monbusho in 1989 and purposes to promote academic researches and to cope with remarkable changes in recent scientific situations. In concrete terms, Monbusho will flexibly and promptly select research fields to be promoted as circumstances may determine, and allot researchers and research funds on a priority basis to each selected subject. As one of the subjects under this category, a research project entitled "Studies of Global Environmental Change with Special Reference to Asia and Pacific Regions (SGEC)" was started in 1990 as a form of an international joint project. It is hardly necessary to point out that this project was organized in the recognition of importance and urgency to protect the global environment (Tamura, 1991).

\section{SGEC and Its Sub-Projects}

SGEC with a further explanatory title "Integrated Development of Environmental Sciences of the World" was organized by international and inter-institutional cooperation, to carry out the long-term observation of the ecosystem change and distribution and circulation of greenhouse gases evolved from the biosphere to the atmosphere. It started in 1990, continued till 1994, and aimed at analyzing the atmospheric dynamism, which transport greenhouse gases to the stratosphere of the atmosphere, destroying the ozone layer. It emphasized the chemical and biological process in the equatorial regions, especially Asian tropics (Anon., 1991).

SGEC was composed of two sub-projects, "Research on Climatic Change over the Asia 
and Pacific Ocean" and "Terrestrial Ecosystem Mechanism of Environmental Changes in Asia (TEMECA)", both of which were further separated into several programs. Out of the sub-projects, the former was mainly organized by climatologists, while the latter was organized by biological scientists. LTLSR at Lambir was enrolled in a research program belonging to the latter sub-project TEMECA (Anon., 1991).

\section{Sub-Project TEMECA and Its Programs and Sub-Programs}

TEMECA consisted of three major research programs; "Kinetic Behaviors of Greenhouse Gasses in Terrestrial Ecosystems of Asian Zones", "Deforestation of Tropical Forests and the Process of Ecological Changes in Southeast Asia (DTF-PECSEA)", and "Deforestation and Reforestation of Ecosystem Due to Human Activities in East Asia". The first was conducted in Thailand with reference to the methane dynamics in the rice paddy. The second including LTLSR in Sarawak was organized by three sub-programs carried out in Thailand, Sarawak, and the neotropics in the American continent, respectively. The details of the sub-program extended in Sarawak are given in a later section. The third was carried out in China with respect to the saline soil and air pollution (Anon., 1991).

\section{Research Program of DTF-PECSEA and Its Sub-Programs}

DTF-PECSEA was handled by the Project Subleader Dr. Yasuo Takai (Professor, Tokyo University of Agriculture, JPN) and a research group designated "Tropical Forest Team (TFT)" composed of about 30 participants including four of us (K.O., I.Y., T.Y. \& T.I.). Senior participants of TFT organized three sub-programs at different forest ecosystems; 1) Sarawak Tropical Forest Ecosystem, 2) Narathiwat Coastal Swamp Forest Ecosystem, and 3) Comparative Studies of Tropical Rain Forests on Three Continents. The conceptual background of DTF-PECSEA is given below (Anon., 1991).

The radically diminishing area and retreating plant life of tropical forests are seriously and adversely affecting the global environment. The annual diminution of 11 million hectares of forest area, decrease of biotic and genetic resources, deterioration of the earth's ecology, destruction of water conservation systems, erosion of soil, etc. are exerting serious impact upon the environment and resource situation. Moreover, the accelerated release of carbon dioxide and its weakened absorbance power of plants have contributed to global warming (Anon, 1991).

The tropics offer an optimum living environment for animal life too. This is particularly true of tropical forests which consist of stratified tall trees and support creatures pursuing their complete life cycles there. However, the structure and function of tropical forests are relatively unknown. Regrettably, many tropical forests have been exploited under the pressure of growing human settlement and are rapidly disappearing even before undergoing scientific observation. The research in DTF-PECSEA primarily focus upon the tropical forests of Southeast Asian islands. Studies will be the logging of virgin forests, structural changes of plant life by forest-burning for farming, forest reproduction process, ecology and physiology of flora and fauna, earth and water environment, nutritional recycling, gas metabolism, etc. These studies will be conducted under a long-term surveillance program to analyze the little known plant life structure and function of tropical forests, and their linkage to the environment. The impact of human disruption to the role of tropical forests in protecting the global environment will be also looked into (Anon. 1991). 
The primary target will be the conservation of rain forest formations on dry land and wet land, respectively, by broadly surveying Southeast Asia. The second target will be a comparison of the present situations of tropical forests among three continents, by doing the small scale forest surveys and by analyzing the former data obtained through international cooperation with European and North American researchers. In this way, the structural and functional characteristics of Southeast Asian tropical rain forests will be clarified and shared among peoples in the world (Anon, 1991).

\section{INTEGRATED RESEARCH PROJECT ON SARAWAK TROPICAL FOREST ECOSYSTEM}

The senior members of the aforementioned program, DTF-PECSEA of the sub-project TEMECA in the project SGEC by the foundation CFR, visited Sarawak in January 1991, following the travel programs extended in Thailand, Peninsular Malaysia, Indonesia (Java and Sumatra), Africa, and neotropical countries during 1989 and 1990. They were Dr. Saburo Tamura, Dr. Yasuo Takai, and two of us (K.O. \& I.Y.) and decided the support to LTLSR at Lambir, since T.Y. had budget troubles as already described. T.Y. was enrolled in DTFPECSEA in 1992, after spending his own modest budget from Monbusho. Thus, an integrated research project, which covered LTLSR and consisted of a subprogram of DTF-PECSEA, started from 1991. The subprogram was entitled "Sarawak Tropical Forest Ecosystem" by DTF-PECSEA, as already described.

\section{Purpose and Justification}

The ultimate goal of the research project is to establish an ecosystem technology for tropical forest ecosystem restoration applicable not only to Sarawak but also to humid tropical forest. Any one ecosystem is deemed to be a highly complicated interactive system of not only biological but also social process. The system is defined as socio-ecosystem (Ogino, 1990). An ecosystem technology should, therefore, duly involve biological as well as social aspects. However, the project is tentatively aiming at clarifying the biological process of the Sarawak tropical forest ecosystem, in order to provide basic information fundamental to forest ecosystem restoration. The in situ field studies shall be carried out at LTLSR site established in Lambir National Park.The biological process functioning in the ecosystem is a primary concern of the project. Because of the valuable resource importance, biologically highly diversified existence, and unexplored biological mechanisms specific to the ecosystem, the tropical forest needs urgent research activities to be extended. In order to achieve the research purpose, the project is coordinated by one of us (K.O.) (Anon., 1991).

\section{Research Project Target}

The target of the project is organized by different research requirements given below (Anon., 1991).

1. Analysis of forest community/population dynamics by a long-term ecological research scheme.

2. Studies on ecophysiological properties of key species.

3. Studies on the species behavior, tree architecture, and life strategy.

4. Ecology of the rhizosphere or studies of interactive systems between plant and soil 




micro-environment.

5. Canopy biology and studies of the interdependency between animals and plants and between organisms and climate.

6. Micro-climate analysis.

7. Socio-ecosystem analysis.

8. Studies on the carbon cycling, primary productivity, and $\mathrm{CO}_{2}$ evolution.

9. Implementation of the socio-ecosystem technology.

\section{Progress}

A 52 ha research plot, which was the largest among all the similar research plots in the word, was established in 1993 by spending four years. The plot was divided into $1300,20 \mathrm{~m} \times 20 \mathrm{~m}$ quadrats and further divided into 20,800 suquadrats $5 \mathrm{~m} \times 5 \mathrm{~m}$, by establishing 21,109 land marks within the plot (Fig. 2). A total of 358,905 trees $1.0 \mathrm{~cm}$ and greater in stem diameter at breast height (dbh) were individually labeled, mapped, identified to species, and measured by $\mathrm{dbh}$. The species identification has been continuing since 1991 and its finalization is expected by Dr. P.S.A. in the earliest opportunity. The data thus obtained are now analyzing and will be reported in several separate papers (e.g., Yamakura et al., in contribution). The Japanese cost for plot establishment was paid by the budget from CFR and small budgets offered to T.Y. by Monbusho (Grant No. 2041071) and Japan Environmental Agency.

The tree tower and walkway system was adopted for the facility of canopy biology. Its construction began in July 1992 after one year preparation in 1991. K.O. took T.I. to Sarawak in August 1991 and discussed with Mr. H.S.L. concerning detailed procedures for constructing the system, including further research proposals to the Sarawak state government. The system was consisted of two tall towers made of Borneo iron wood and nine spans of aerial walkways between towers and was built following a plan proposed by T.I. (Fig. 3). The first tower, was 


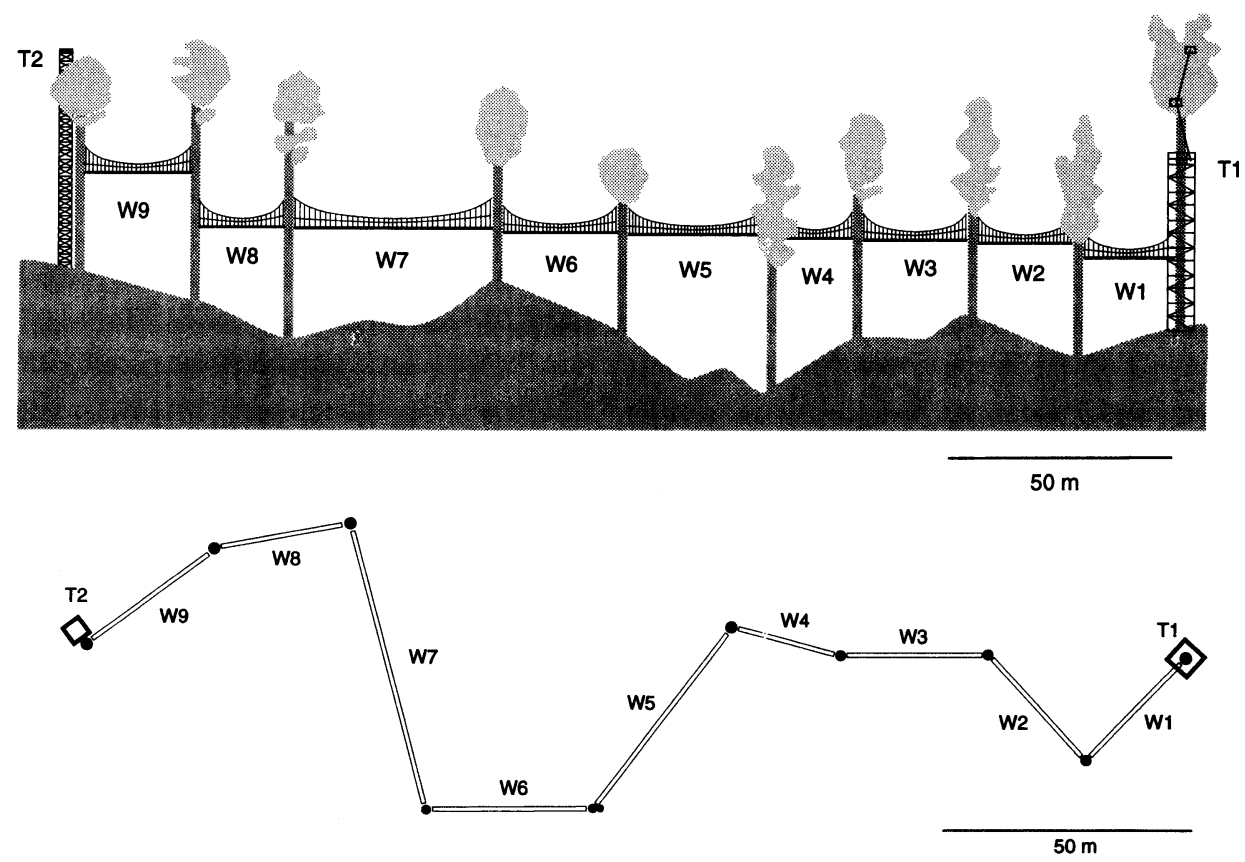

Fig. 3. The vertical profile (upper) and plan (lower) of the tree tower and walkway system for canopy biology (Reproduced from an original figure by Inoue and Hamid, 1994).

built around an emergent tree of Dryobalanops lanceolata on a low ridge outside the 52 ha plot and was opened to the publicity in December 1992. The construction of the whole system finished in April 1993. For the further details of the tree towers, see the separate report written by Inoue \& Hamid (1994). A variety of researches was carried out by using the system, to cope with the research subjects described in the aforementioned section of the research project target (cf., Inoue \& Hamid, 1994). All the costs for the system construction was paid by the budgets from CFR sponsored by Monbusho and the donation from Marubeni Co. Ltd. to Ehime University. The cost for the dispatch of some Japanese entomologists to Sarawak and miscellaneous consumption for entomological studies were paid by the another Monbusho's modest grant defrayed to T.I. (Grant No. 4041067). The cost for tree physiology researches by Dr. Ikuo Ninomiya (Associate Professor, Ehime University, JPN) and his colleagues in canopies was paid by the budget from CFR.

A biological laboratory was established in 1993, by using the CFR budget. It was equipped by the personal computer, electric air oven, electric balance, refrigerator, clean bench, and small herbarium, etc., for the monitoring of the 52 ha plot, canopy biology, tree physiology, pedology, etc.

\section{Reconsideration and Future Perspectives}

We successfully passed the first phase of the integrated research project at Lambir by establishing the large-scale research plot, tree tower walkway system, and laboratory facility. The project will be continued for several decades at the least by using these facilities. However, we understand well that we have left many things unsolved. For example, the initiation of LTLSR in Brunei is still floating and is expected to be solved by I.Y. or 
somebodies in the nearest future. We can honestly recommend the further establishment of LTLSR sites within Asian countries along altitudinal and latitudinal gradients for comparative studies, since the LTLSR site at Lambir is one of representative research sites (Fig. 1). To combine and to support these research sites in Asia including Japan, we need an international research institute specialized to tropical ecology in the region.

ACKNOWLEDGEMENTS Our profound thanks are due to the State Government Sarawak for his helpful support. We also wish to thank to Datuk Leo Chai, the Director of Forests, Forest Department Sarawak, Emeritus Professor Saburo Tamura, University of Tokyo, and Professor Yasuo Takai, Tokyo University of Agriculture, for their attentive general suggestions during the course of the project. We are also indebted to Professor Peter Shaw Ashton, Harvard University, for his kind guidance to Sarawak rain forest and friendly cooperation in preparing the project. We owe much to Mr. Hua Seng Lee, the Assistant Director of Forests (Research), Forest Department Sarawak, Mr. Ernest Chai Oi Khun, the Silviculturist, Forest Department Sarawak, and Mr. Abang Abdul Hamid, the Entomologist, Forest Department Sarawak, for their friendly cooperation throughout researches. We thank much to the Marubeni Co. Ltd. for his generous financial support. We have appreciated the help and constructive criticisms of the members of JASTE.

\section{REFERENCES}

Anon. 1991. Studies of global environmental change with special reference to Asia and Pacific regions-integrated development of environmental sciences of the world. Earth Ecology and Climate 2: 2-32.

Ashton, P. S. 1964. Ecological Studies in the Mixed Dipterocarp Forests of Brunei State. Oxford memoirs 25. Clarendon Press, Oxford.

1991. Toward a regional classification of the humid tropics of Asia. Tropics 1: 1-12. 1989. Funding Priorities for Research toward Effective Sustainable Management of Biodiversity Resources in Tropical Asia. Report of a workshop sponsored by NSF and USAID, Bangkok, March 27-30.

Austin, M. P., Ashton, P. S. \& Greig-Smith, P. 1973. The application of quantitative methods to vegetation survey. III. A reexamination of rain forest data from Brunei, Journal of Ecology 60: 309-324.

Baillie, I. C. \& Ashton, P. S. 1983. Some soil aspects of the nutrient cycle in mixed dipterocarp forests in Sarawak. In: Sutton, S. L., Whitmore, T. C., \& Chadwick, A. C.(eds.), Tropical Rain Forest: Ecology and Management, 347-356. Blackwell, Oxford.

$\longrightarrow$, Court, M. N., Anderson, J. A. R., Fitzpatrick, E. A. \& Tinsley, J. 1987. Site characteristics and the distribution of tree species in mixed dipterocarp forests on tertiary sediments in Central Sarawak, Malaysia. Journal of Tropical Ecology 3: 201-220.

Chai, E. O. K., Lee, H. S. \& Yamakura, T. Preliminary results of the 52 hectare long-term ecological research plot at Lambir Hills National Park, Miri, Sarawak, Malaysia. In: Lee, H.S., Ogino, K. \& Ashton, P. S. (eds.), Long-Term Ecological Research in Relation to Forest Ecosystem Management. Government Printer, Kuching (in press).

Erwin, T. L. 1983. Beetles and other insects of tropical forest canopies at Manaus, Brazil, sampled by insecticidal fogging. In: Sutton, S. L., Whitmore, T. C., \& Chadwick, A. C. 
(eds.), Tropical Rain Forest: Ecology and Management, 59-75. Blackwell, Oxford.

— 1988. The tropical forest canopy-the heart of biotic diversity. In: Wilson, E. O. \& Peter F. M. (eds.), Biodiversity, 123-129. National Academy Press, Washington.

Hubbell, S. P. \& Foster, R. B. 1983. Diversity of canopy trees in a neotropical forest and implications for conservation. In: Sutton, S. L., Whitmore, T. C., \& Chadwick, A. C.(eds.), Tropical Rain Forest: Ecology and Management, 25-41. Blackwell, Oxford.

Hotta, M. 1964. Kyoto University Borneo expedition conducted in 1963 and 1964. Tanken 8:

1-8 (in Japanese with English summary).

- 1965. Itinerary of the Borneo (notes on the vegetation). Acta Phytotax. Geobot. 21:

153-160 (in Japanese).

1967. Forests in Sarawak and Brunei. Sanrin 992: 1-7 (in Japanese).

(ed.), 1984. Forest Ecology and Flora of G. Gadut, West Sumatra. Sumatra Nature Study (Botany), Kyoto.

Inoue, T. \& Hamid, A. A. (eds.), 1994. Plant Reproductive Systems and Animal Seasonal Dynamics. Center for Ecological Research, Kyoto University, Shiga.

Katagiri, S., Yamakura, T. \& Lee, H. S. 1991. Properties of soils in kerangas forest on sandstone at Bako National Park, Sarawak, East Malaysia. Southeast Asian Studies 29: 35-48.

Likens, G. E. (ed.) 1989. Long-term Studies in Ecology: Approaches and Alternatives. Springer, New York.

Ogino, K. 1990. Tropical forest ecosystem. In: Ohkita, S. (ed.), Environmental Problems in Earth Scale, II, 14-26. Chyuou-houki Syuppan, Tokyo (in Japanese).

- 1992. Mangrove ecosystem. In: Shidei, T. \& Kira, T. (eds.), Discussions of Tropical Rain Forest, 180-207. Jinbun-Syoin, Kyoto (in Japanese).

Panayoto, T. \& Ashton, P. S. 1992. Not by Timber Alone. Island Press, Washington.

Sakagami, S., Ohgushi, F. \& Roubik, D. W. (eds.) 1990. Natural History of Social Wasps and Bees in Equatorial Sumatra. Hokkaido University Press, Sapporo.

Tamura, S., 1991. Towards the new development of global environmental sciences. Earth Ecology and Climate 2: 1.

Whitmore, T. C. 1984. Tropical Rain Forests of the Far East (2nd ed.), Clarendon Press, Oxford.

Yamada, I. 1991. The World of Tropical Rain Forests in Southeast Asia. Sobunsya, Tokyo (in Japanese).

Yamakura, T. 1992. Long-term and large-scale observation of mixed dipterocarp forest. Earth Ecology \& Climate 3: 3-7 (in Japanese).

_. 1993. Long-term observation of tropical rain forest. Kagaku 63: 755-756 (in Japanese).

- 1994. Establishment of a large-scale research plot and long-term monitoring. In: Ichikawa, A. (ed.), Science of Global Environmental Change, II., 116-129. Kuba Pro, Tokyo (in Japanese).

—. A. Hagihara, S. Sukardjo \& H. Ogawa, 1986. Aboveground biomass of tropical rain forest stands in Indonesian Borneo. Vegetatio 68: 71-82.

- et al. Topography of a large-scale research plot established within the Lambir rain forest in Sarawak. Tropics (in contribution). 
山倉拓夫, 山田 勇, 井上民二, 荻野和彦 サラワク州ランビル熱帯雨林の大面積 長期観察：日本の研究活動の進展とその思想的背景

1990 年からサラワク州ランビル国立公園で熱帯雨林の大面積長期観察を開始した。1994 年に至 る過去 5 年間の活動を通じて, 52 ha 大面積調査区, ツリータワーと空中回廊システム, および 実験棟を建設し, 研究基盤を整備した。この小論ては, 研究開始から現在に至る研究活動, 林冠 生物学の定義とその開始, 及びこれからの諸活動の背景となる基本的考え方をのべた。これらの 記述が, 他の調査地での類似研究の推進に資すると共に, 本誌で発表される関連論文の理解の一 助となることを期待する。 